\title{
Effects of Y Substitution for La on the Microstructure and Electrochemical Properties of $\mathrm{LaNi}_{3.55} \mathrm{Mn}_{0.4} \mathrm{Al}_{0.3} \mathrm{Co}_{0.75}$ Hydrogen Storage Alloys
}

\author{
W. Li*1 and Y. L. Du*2 \\ Department of Materials Science and Engineering, Nanjing University of Science and Technology, 210094, Nanjing, P.R.China
}

\begin{abstract}
The effects of the partial substitution of $\mathrm{Y}$ for $\mathrm{La}$ in $\mathrm{La}_{1-x} \mathrm{Y}_{x} \mathrm{Ni}_{3.55} \mathrm{Mn}_{0.4} \mathrm{Al}_{0.3} \mathrm{Co}_{0.75}(x=0,0.1$ and 0.2$)$ alloys were reported in this paper. The single-phase $\mathrm{CaCu}_{5}$-type structure is retained after La is partially substituted by $\mathrm{Y}$. However, the increase of $\mathrm{Y}$ content leads to decrease of the lattice parameters and unit-cell volume. Y substitution for La in the alloys is effective to improve the electrochemical properties at room temperature and high temperature. A critical substitution content of $\mathrm{Y}$ is found at $x=0.1$. [doi:10.2320/matertrans.MA200809]
\end{abstract}

(Received April 1, 2008; Accepted May 28, 2008; Published July 16, 2008)

Keywords: hydrogen storage alloys, nickel/metal-hydride batteries, high-temperature electrochemical properties

\section{Introduction}

The $\mathrm{AB}_{5}$-type hydrogen storage alloys have been used as negative electrodes in nickel/metal-hydride $(\mathrm{Ni} / \mathrm{MH})$ batteries because of their good overall electrochemical properties and low-cost. ${ }^{1-5)}$ In recent years, the research and development of high-power type $\mathrm{Ni} / \mathrm{MH}$ battery for application in electric vehicles have attracted considerable attentions. The discharge electric current in electric vehicles is much higher than that in portable electronic applications. As a result, the ambient temperature might be increased to $60^{\circ} \mathrm{C}^{6)}$ It is so high that the electrochemical properties of the commercialized $\mathrm{AB}_{5}$-type hydrogen storage alloys will deteriorate seriously. Therefore, how to improve the hightemperature electrochemical properties has actual significance in developing the high-power type $\mathrm{Ni} / \mathrm{MH}$ battery. It is well known that the element substitution is an effective way to improve the electrochemical properties of $\mathrm{AB}_{5}$-type hydrogen storage alloys. For example, the partial substitution of $\mathrm{La}$ in $\mathrm{A}$ side by $\mathrm{Ce}, \mathrm{Pr}, \mathrm{Nd}$, and the partial substitution of $\mathrm{Ni}$ in $\mathrm{B}$ side by $\mathrm{Co}, \mathrm{Mn}, \mathrm{Al}$, etc. have been extensively investigated. ${ }^{7-11)}$ In additional, the low-temperature performances of $\mathrm{AB}_{5}$-type hydrogen storage alloys have been successfully improved by adjusting the rare earth composition in A side. ${ }^{12)}$ So, the high-temperature electrochemical properties of $\mathrm{AB}_{5}$-type hydrogen storage alloys might also be improved by multi-component alloying. It was reported that alloying with element $\mathrm{Y}$ could form a Y-containing passive layer on the surface of the powders in $\mathrm{LaNi}_{4.7} \mathrm{Sn}_{0.3}$ alloy. ${ }^{13)}$ The existence of this $\mathrm{Y}$-containing layer can decrease the corrosion rate and improve the hydriding/dehydriding reactions of the alloy at room temperature. ${ }^{13)}$ Based on these results, the improvement of high-temperature electrochemical properties of $\mathrm{AB}_{5}$-type alloys by alloying with $\mathrm{Y}$ is expected. Thus, in this paper, $\mathrm{La}_{1-x} \mathrm{Y}_{x} \mathrm{Ni}_{3.55} \mathrm{Mn}_{0.4} \mathrm{Al}_{0.3} \mathrm{Co}_{0.75}$ alloys with different $\mathrm{Y}$ concentrations were prepared and the effects of $\mathrm{Y}$ substitution for La on the microstructure and electrochemical properties including the high-temperature performance of $\mathrm{LaNi}_{3.55} \mathrm{Mn}_{0.4} \mathrm{Al}_{0.3} \mathrm{Co}_{0.75}$ hydrogen storage alloys were studied. $\mathrm{LaNi}_{3.55} \mathrm{Mn}_{0.4} \mathrm{Al}_{0.3} \mathrm{Co}_{0.75}$ alloy was

\footnotetext{
${ }^{* 1}$ Graduate Student, Nanjing University of Science and Technology

${ }^{* 2}$ Corresponding author, E-mail: yldu_njust@126.com
}

adopted as a base alloy because it was a typical commercialized $\mathrm{AB}_{5}$-type hydrogen storage alloy and also showed good overall electrochemical properties.

\section{Experimental Procedure}

The $\mathrm{La}_{1-x} \mathrm{Y}_{x} \mathrm{Ni}_{3.55} \mathrm{Mn}_{0.4} \mathrm{Al}_{0.3} \mathrm{Co}_{0.75}(x=0,0.1$ and 0.2$)$ alloy samples were prepared by arc-melting technique under argon atmosphere. To assure the homogeneity, the alloy ingots were turned over and remelted at least 3 times. $\mathrm{X}$-ray diffraction (XRD) measurements were performed in a Rigaku D/Max-RA diffractometer with $\mathrm{Cu} \mathrm{K} \alpha$ radiation. The surface morphologies of these samples were studied by using an Olympus optical electron microscope (OEM). The test pieces were made by polishing and etching $(10 \mathrm{ml}$ $\left.\mathrm{HF}+20 \mathrm{ml} \mathrm{HNO}_{3}+70 \mathrm{ml} \mathrm{C}_{2} \mathrm{H}_{5} \mathrm{OH}\right)$. For electrochemical experiments, all samples were mechanically pulverized to below 200 mesh. The electrodes were prepared by cold pressing to pellets after mixing the alloy powder with copper powder in a weight ratio of $1: 2$. The electrochemical experiments were made in $6 \mathrm{M} \mathrm{KOH}$ electrolyte, using a sintered nickel plate as a counter electrode, and a mercury oxide electrode $(\mathrm{Hg} / \mathrm{HgO})$ as the reference electrode. The electrodes were charged at a current density of $100 \mathrm{~mA} / \mathrm{g}$ for $5 \mathrm{~h}$ and discharged at a current density of $50 \mathrm{~mA} / \mathrm{g}$. The discharging cut-off potential was $-0.6 \mathrm{~V}$ versus $\mathrm{Hg}$ / $\mathrm{HgO}$ electrode.

\section{Results and Discussion}

\subsection{Structural properties}

Figure 1(a) shows the XRD patterns of the as-cast $\mathrm{La}_{1-x} \mathrm{Y}_{x} \mathrm{Ni}_{3.55} \mathrm{Mn}_{0.4} \mathrm{Al}_{0.3} \mathrm{Co}_{0.75}(x=0,0.1$ and 0.2$)$ alloys. It can be seen that the $\mathrm{LaNi}_{3.55} \mathrm{Mn}_{0.4} \mathrm{Al}_{0.3} \mathrm{Co}_{0.75}$ alloy exhibits the diffraction peaks corresponding to the single-phase of $\mathrm{LaNi}_{5}$ (PDF card no. 50-0777) with the hexagonal $\mathrm{CaCu}_{5}-$ type structure. As La is partially substituted by $\mathrm{Y}$, no new diffraction peaks are observed, indicating that the singlephase structure is retained. Rietveld refining was used to further analyze the phase structure and to calculate the lattice constant. Figure 1(b) shows the result of the Rietveld analyis for the $\mathrm{La}_{0.9} \mathrm{Y}_{0.1} \mathrm{Ni}_{3.55} \mathrm{Mn}_{0.4} \mathrm{Al}_{0.3} \mathrm{Co}_{0.75}$ alloy. An excellent fitting to single-phase with $\mathrm{CaCu}_{5}$-type structure was 

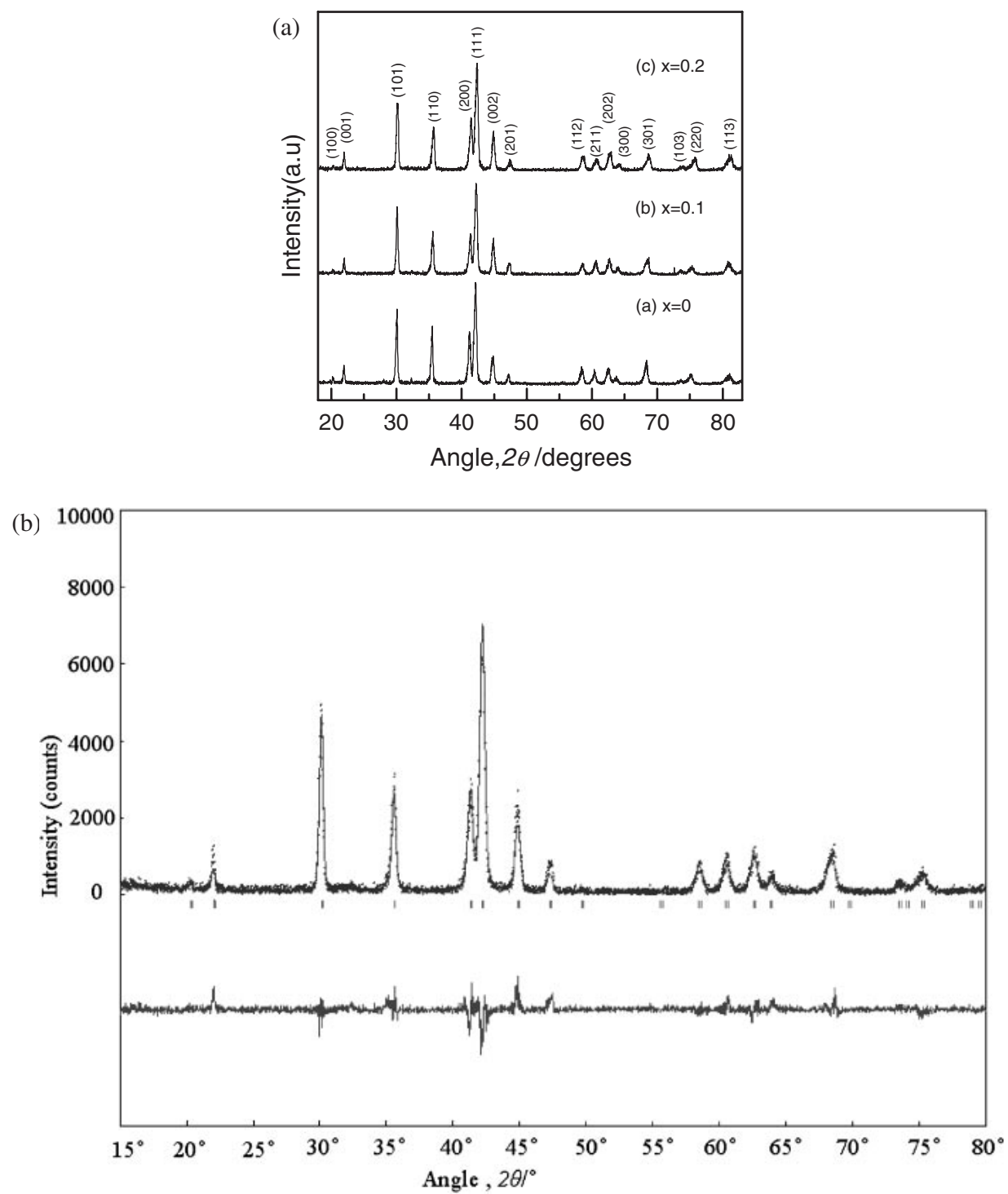

Fig. 1 (a) XRD patterns of $\mathrm{La}_{1-x} \mathrm{Y}_{x} \mathrm{Ni}_{3.55} \mathrm{Mn}_{0.4} \mathrm{Al}_{0.3} \mathrm{Co}_{0.75}$ alloys; (b) Rietveld refining of the XRD pattern of $\mathrm{La}_{0.9} \mathrm{Y}_{0.1} \mathrm{Ni}_{3.55} \mathrm{Mn}_{0.4}{ }^{-}$ $\mathrm{Al}_{0.3} \mathrm{Co}_{0.75}$.

Table 1 Lattice constants and cell volume of $\mathrm{La}_{1-x} \mathrm{Y}_{x} \mathrm{Ni}_{3.55} \mathrm{Mn}_{0.4^{-}}$ $\mathrm{Al}_{0.3} \mathrm{Co}_{0.75}(x=0,0.1$ and 0.2$)$ alloys.

\begin{tabular}{cccc}
\hline \multirow{2}{*}{ Sample } & \multicolumn{2}{c}{ Lattice constants } & Cell volume \\
\cline { 2 - 3 } & $a(\AA)$ & $c(\AA)$ & $\left(\AA^{3}\right)$ \\
\hline$x=0.0$ & 5.07321 & 4.04405 & 90.1390 \\
$x=0.1$ & 5.05699 & 4.04384 & 89.6255 \\
$x=0.2$ & 5.04127 & 4.04372 & 89.0005 \\
\hline
\end{tabular}

obtained, which indicated that substituting La by $\mathrm{Y}$ had no influence on the phase structure. The obtained lattice parameters and cell volumes for $\mathrm{La}_{1-x} \mathrm{Y}_{x} \mathrm{Ni}_{3.55} \mathrm{Mn}_{0.4} \mathrm{Al}_{0.3^{-}}$ $\mathrm{Co}_{0.75}(x=0,0.1$ and 0.2$)$ alloys were listed in Table 1 . It is seen that the lattice constants $a$ and $c$, and the cell volume decreased with increasing the content of $\mathrm{Y}$. This is due to the smaller atomic radius of $\mathrm{Y}$ than that of $\mathrm{La}$. The reduction in the cell volume will increase the equilibrium hydrogen pressure, which will influence the hydrogen storage and electrochemical properties of the alloys. Figure 2 shows the optic photographs of the $\mathrm{La}_{1-x} \mathrm{Y}_{x} \mathrm{Ni}_{3.55} \mathrm{Mn}_{0.4} \mathrm{Al}_{0.3} \mathrm{Co}_{0.75}$ $(x=0,0.1$ and 0.2$)$ alloys. It can be seen that the as-cast $\mathrm{LaNi}_{3.55} \mathrm{Mn}_{0.4} \mathrm{Al}_{0.3} \mathrm{Co}_{0.75}$ alloy is of a typical dendrite structure. The $\mathrm{La}_{0.9} \mathrm{Y}_{0.1} \mathrm{Ni}_{3.55} \mathrm{Mn}_{0.4} \mathrm{Al}_{0.3} \mathrm{Co}_{0.75}$ alloy exhibits the similar dendrite structure. However, as the $\mathrm{Y}$ content increased further, the coarse dendrites formed in the $\mathrm{La}_{0.8} \mathrm{Y}_{0.2} \mathrm{Ni}_{3.55} \mathrm{Mn}_{0.4} \mathrm{Al}_{0.3} \mathrm{Co}_{0.75}$ alloy as shown in Fig. 2(c). The presence of the coarse dendrite structure indicates that the considerable elemental segregation occurred with increasing the content of $\mathrm{Y}$, which will cause the bad electrochemical properties.

\subsection{Electrochemical properties}

The cycle behavior at $298 \mathrm{~K}$ of the $\mathrm{La}_{1-x} \mathrm{Y}_{x} \mathrm{Ni}_{3.55^{-}}$ $\mathrm{Mn}_{0.4} \mathrm{Al}_{0.3} \mathrm{Co}_{0.75}(x=0,0.1$ and 0.2$)$ alloys was shown in Fig. 3. It can be seen that the discharge capacities of all the samples reach the maximum value after 2 or 3 chargedischarge cycles, showing good activation behavior. Thus, the good activation properties of $\mathrm{LaNi}_{3.55} \mathrm{Mn}_{0.4} \mathrm{Al}_{0.3} \mathrm{Co}_{0.75}$ alloy were retained after substituting $\mathrm{Y}$ for $\mathrm{La}$. The cycle life 


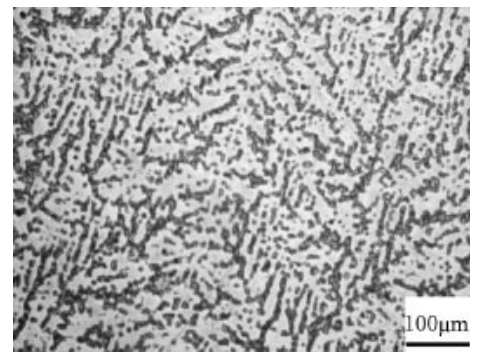

(a)

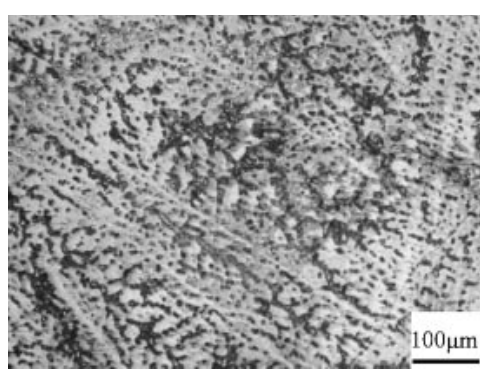

(b)

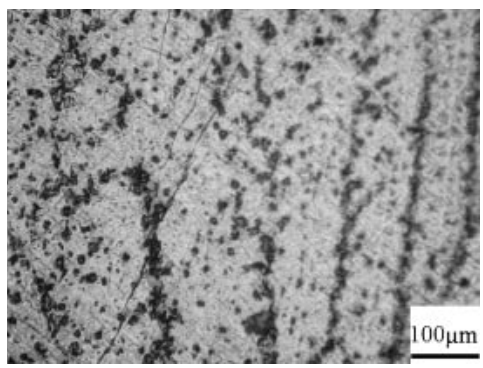

(c)

Fig. 2 The optic photographs of the as-cast $\mathrm{La}_{1-x} \mathrm{Y}_{x} \mathrm{Ni}_{3.55} \mathrm{Mn}_{0.4} \mathrm{Al}_{0.3} \mathrm{Co}_{0.75}$ alloys (a) $x=0$; (b) $x=0.1$; and (c) $x=0.2$.

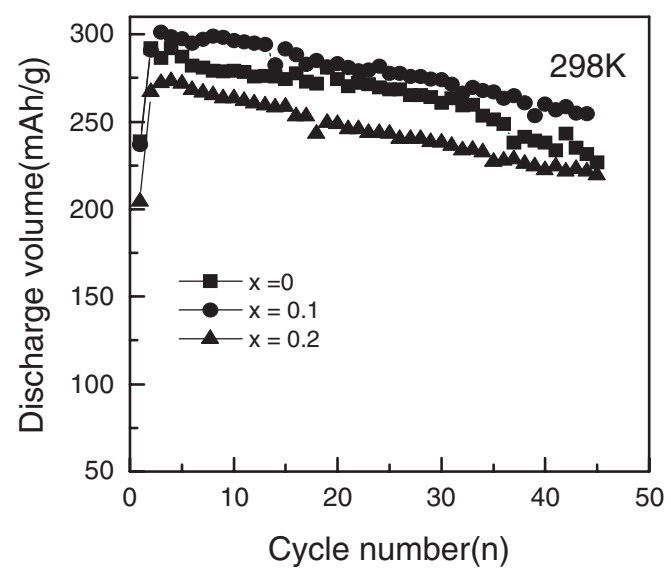

Fig. 3 Cycle behavior of the $\mathrm{La}_{1-x} \mathrm{Y}_{x} \mathrm{Ni}_{3.55} \mathrm{Mn}_{0.4} \mathrm{Al}_{0.3} \mathrm{Co}_{0.75} \quad(x=0,0.1$ and 0.2 ) electrodes at $298 \mathrm{~K}$.

of the $\mathrm{La}_{0.9} \mathrm{Y}_{0.1} \mathrm{Ni}_{3.55} \mathrm{Mn}_{0.4} \mathrm{Al}_{0.3} \mathrm{Co}_{0.75}$ hydride electrodes is the best and the degradation of the alloys is about $10 \%$ after 44 charge-discharge cycles. But when the content of $\mathrm{Y}$ increases further $(x=0.2)$, the cycle life decreases rapidly; the degradation rates of the discharge capacity are about $19.8 \%$ after 44 cycles. The cycle behavior of the

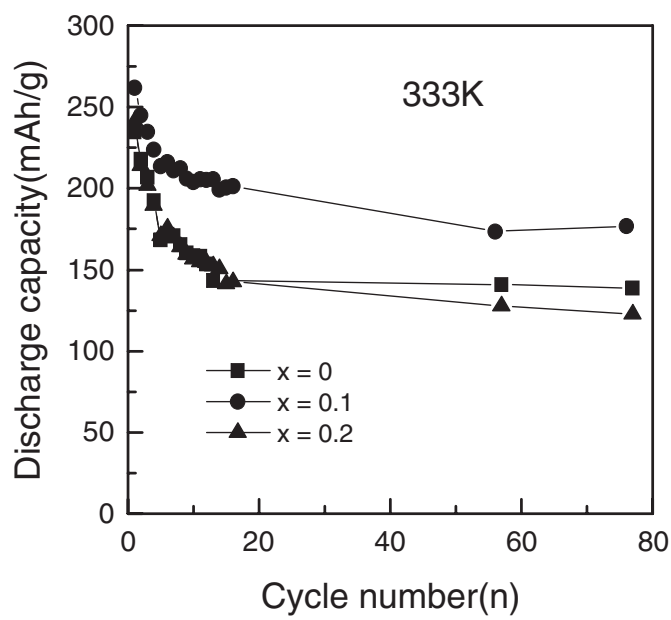

Fig. 4 Cycle behavior of the $\mathrm{La}_{1-x} \mathrm{Y}_{x} \mathrm{Ni}_{3.55} \mathrm{Mn}_{0.4} \mathrm{Al}_{0.3} \mathrm{Co}_{0.75}(x=0,0.1$ and 0.2 ) electrodes at $333 \mathrm{~K}$.

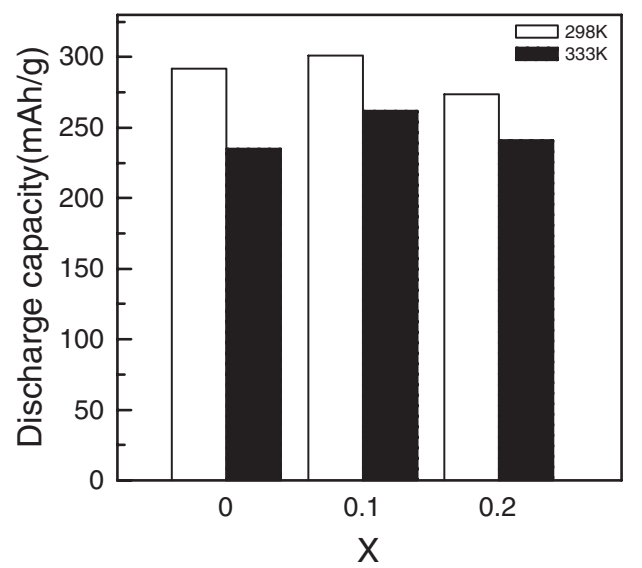

Fig. 5 The maximum discharge capacities of $\mathrm{La}_{1-x} \mathrm{Y}_{x} \mathrm{Ni}_{3.55} \mathrm{Mn}_{0.4^{-}}$ $\mathrm{Al}_{0.3} \mathrm{Co}_{0.75}(x=0,0.1$ and 0.2$)$ electrodes at $298 \mathrm{~K}$ and $333 \mathrm{~K}$.

$\mathrm{La}_{1-x} \mathrm{Y}_{x} \mathrm{Ni}_{3.55} \mathrm{Mn}_{0.4} \mathrm{Al}_{0.3} \mathrm{Co}_{0.75}(x=0,0.1$ and 0.2$)$ alloys at $333 \mathrm{~K}$ is shown in Fig. 4. The discharge capacity reaches the maximum at the first cycle for all the samples. When $\mathrm{x}$ equals 0.1 , the degradation of the alloy is only about $33 \%$ after 76 charge-discharge cycles. But when the content of $\mathrm{Y}$ increases further $(x=0.2)$, the degradation rates of the discharge capacity are about $49 \%$ after 76 cycles. The maximum discharge capacities of the $\mathrm{La}_{1-x} \mathrm{Y}_{x} \mathrm{Ni}_{3.55} \mathrm{Mn}_{0.4^{-}}$ $\mathrm{Al}_{0.3} \mathrm{Co}_{0.75}(x=0,0.1$ and 0.2$)$ alloys electrodes tested at 298 and $333 \mathrm{~K}$ were shown in Fig. 5. At $298 \mathrm{~K}$, the maximum discharge capacity increases to $301 \mathrm{mAh} / \mathrm{g}$ as the content of $\mathrm{Y}$ in the alloy increases from $x=0$ to 0.1 . However, as the $\mathrm{Y}$ content further increased, the maximum discharge capacity decreased to $274 \mathrm{mAh} / \mathrm{g}$. In addition, at $333 \mathrm{~K}$, the maximum discharge capacity for all the samples decreased. But the $\mathrm{La}_{0.9} \mathrm{Y}_{0.1} \mathrm{Ni}_{3.55} \mathrm{Mn}_{0.4} \mathrm{Al}_{0.3} \mathrm{Co}_{0.75}$ alloy shows the highest discharge capacity of $262 \mathrm{mAh} / \mathrm{g}$. The rate dischargeability can be defined as ${ }^{14)}$

$$
\eta=C_{i} /\left(C_{i}+C_{50}\right) \times 100 \%
$$

where $C_{i}$ is the discharge capacity under various current densities $(i=1200 ; 800 ; 400$; and $200 \mathrm{~mA} / \mathrm{g})$, and $\mathrm{C}_{50}$ is the residual discharge capacity at $50 \mathrm{~mA} / \mathrm{g}$ after the elec- 


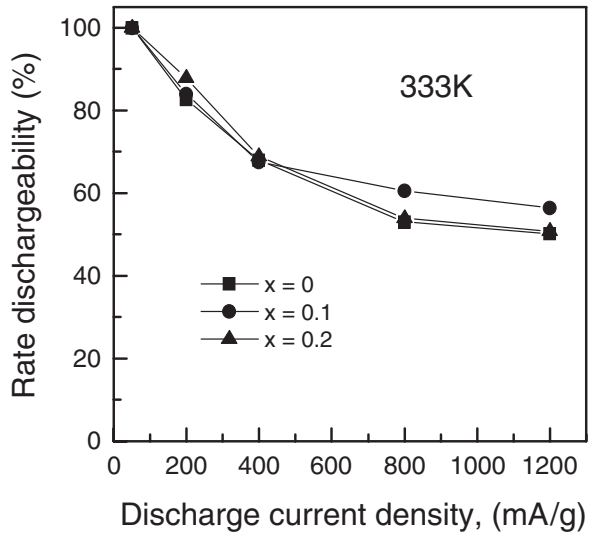

Fig. 6 The rate dischargeability of $\mathrm{La}_{1-x} \mathrm{Y}_{x} \mathrm{Ni}_{3.55} \mathrm{Mn}_{0.4} \mathrm{Al}_{0.3} \mathrm{Co}_{0.75}(x=0$, 0.1 and 0.2 ) electrodes under various $\mathrm{Y}$ concentrations at $333 \mathrm{~K}$.

trode potential fell to $-0.6 \mathrm{~V}$ (vs. $\mathrm{Hg} / \mathrm{HgO}$ ) under the discharge current of $i \mathrm{~mA} / \mathrm{g}$. Figure 6 shows relationship between the rate dischargeability and discharge current of the $\mathrm{La}_{1-x} \mathrm{Y}_{x} \mathrm{Ni}_{3.55} \mathrm{Mn}_{0.4} \mathrm{Al}_{0.3} \mathrm{Co}_{0.75}$ alloys at various $\mathrm{Y}$ concentrations. It can be seen that all the discharge capacities decrease with increasing discharge current. When the discharge current is lower than $400 \mathrm{~mA} / \mathrm{g}$, the rate dischargeability is similar for all the samples. However, the $\mathrm{La}_{0.9} \mathrm{Y}_{0.1^{-}}$ $\mathrm{Ni}_{3.55} \mathrm{Mn}_{0.4} \mathrm{Al}_{0.3} \mathrm{Co}_{0.75}$ alloy shows the highest rate dischargeability as the discharge current makes further increase.

From the present results, it is clear that the hightemperature electrochemical properties of $\mathrm{LaNi}_{3.55} \mathrm{Mn}_{0.4}$ $\mathrm{Al}_{0.3} \mathrm{Co}_{0.75}$ alloy can be improved by the partial substitution of $\mathrm{Y}$ for $\mathrm{La}$. And the $\mathrm{La}_{0.9} \mathrm{Y}_{0.1} \mathrm{Ni}_{3.55} \mathrm{Mn}_{0.4} \mathrm{Al}_{0.3} \mathrm{Co}_{0.75}$ alloy exhibits the best overall electrochemical properties. As reported, ${ }^{13)}$ during the charging/discharging processes, a layer of Y hydrous oxide forms, which can act as a blocking passivating layer. Additionally, the hydriding/dehydriding reactions of the alloy can be improved by alloying with Y. As a result, the cycle life and high-temperature electrochemical properties of the alloy can be improved by the partial substitution of $\mathrm{Y}$ for La. However, as mentioned above, alloying with $\mathrm{Y}$ will increase the equilibrium hydrogen pressure. The equilibrium hydrogen pressure becomes unacceptable high for high Y content, which will weaken the electrochemical properties of the alloy. In addition, the considerable elemental segregation caused by the high content of Y also leads to the bad electrochemical properties. We think that these two factors induced the bad electrochemical properties of $\mathrm{La}_{0.8} \mathrm{Y}_{0.2} \mathrm{Ni}_{3.55} \mathrm{Mn}_{0.4} \mathrm{Al}_{0.3} \mathrm{Co}_{0.75}$ alloy.

\section{Conclusions}

The effects of $\mathrm{Y}$ substitution on the crystal structure and electrochemical properties of $\mathrm{La}_{1-x} \mathrm{Y}_{x} \mathrm{Ni}_{3.55} \mathrm{Mn}_{0.4} \mathrm{Al}_{0.3} \mathrm{Co}_{0.75}$ $(x=0,0.1$ and 0.2$)$ alloys were examined. The following conclusions are arrived. The single-phase $\mathrm{CaCu}_{5}$-type structure is retained after $\mathrm{La}$ is partially substituted by $\mathrm{Y}$. However, increasing the content of $\mathrm{Y}$ leads to the reduction in the lattice parameters and cell volume. $\mathrm{La}_{0.9} \mathrm{Y}_{0.1} \mathrm{Ni}_{3.55^{-}}$ $\mathrm{Mn}_{0.4} \mathrm{Al}_{0.3} \mathrm{Co}_{0.75}$ alloy was found to exhibit the best overall electrochemical properties including the maximum discharge capacity, cycling stability and rate-dischargeability at 298 and $333 \mathrm{~K}$.

\section{Acknowledgements}

This work was supported financially by the Young Scholar Foundation of Nanjing University of Science and Technology (Grant No. Njust200404) and "Qinglan Project" Foundation of Jiangsu Province.

\section{REFERENCES}

1) Y. H. Zhang, X. L. Wang, M. Y. Chen, P. Li, Y. F. Lin and R. Li: Metallic Functiuonal Materials 9 (2002) 1-6.

2) T. Sakai, H. Miyamura, N. Kuriyama, A. Kato, K. Oguro and H. Ishikawa: J. Electrochem. Soc. 137 (1990) 795-799.

3) M. Latroche, Y. Chabre, A. Percheron-Guegan, O. Isnard and B. Knop: J. Alloys Compd. 330-332 (2002) 787-791.

4) S. R. Ovshinsky, M. A. Fetcenko and J. Ross: Science 260 (1993) 176-181.

5) H. Ye, H. Zhang, W. Q. Wu and T. S. Huang: J Alloys Compd. 312 (2000) 68-76.

6) S. Q. Li, L. X. Chen, R. Guo, S. K. Zhang, T. Ying and Y. Q. Lei: Rare Metal Materials and Engineering 32 (2003) 228-231.

7) J. Yu, S. Lee, K. Cho and J. Y. Lee: J. Electrochem. Soc. 147 (2000) 2013-2017.

8) N. Kuriyama, T. Sakai, H. Miyamura, H. Tanaka, I. Uehara, F. Meli and L. Schlapbach: J. Alloys Comp. 238 (1996) 128-140.

9) F. Meli, A. Züttel and L. Schlapbach: J. Alloys Compd. 231 (1995) 639-644.

10) J. J. G. Willems and K. H. J. Buschow: J. Less-Common Met. 129 (1987) 13-30.

11) J. M. Cocciantelli, P. Bernard, S. Fernandez and J. Atkin: J. Alloys Compd. 253-254 (1997) 642-647.

12) H. Ye, B. J. Xia, W. Q. Wu, K. Du and H. Zhang: J. Power Source 111 (2002) 145-151.

13) E. A. Ticianelli, S. Mukerjee, J. McBreen, G. D. Adzic, J. R. Johnson and J. J. Reilly: J. Electrochem. Soc. 146 (1999) 3582-3590.

14) Y. L. Du, X. G. Yang, Q. A. Zhang, Y. Q. Lei and M. S. Zhang: Int. J. Hydrogen Energy 26 (2001) 333-337. 